\title{
Culture versus PCR for Salmonella Species Identification in Some Dairy Products and Dairy Handlers with Special Concern to Its Zoonotic Importance
}

\author{
Mayada M. Gwida ${ }^{1}$ and Maha A. M. AL-Ashmawy ${ }^{2}$ \\ ${ }^{1}$ Department of Hygiene and Zoonoses, Faculty of Veterinary Medicine, Mansoura University, Mansoura 35516, Egypt \\ ${ }^{2}$ Department of Food Hygiene and Control, Faculty of Veterinary Medicine, Mansoura University, Mansoura 35516, Egypt \\ Correspondence should be addressed to Mayada M. Gwida; mayada.gwida@gmail.com
}

Received 6 February 2014; Revised 15 March 2014; Accepted 17 March 2014; Published 3 April 2014

Academic Editor: Francesca Mancianti

Copyright (c) 2014 M. M. Gwida and M. A. M. AL-Ashmawy. This is an open access article distributed under the Creative Commons Attribution License, which permits unrestricted use, distribution, and reproduction in any medium, provided the original work is properly cited.

\begin{abstract}
A total of 200 samples of milk and dairy products as well as 120 samples of dairy handlers were randomly collected from different dairy farms and supermarkets in Dakahlia Governorate, Egypt. The conventional cultural and serotyping methods for detection of Salmonella in dairy products were applied and the results were compared with those obtained by molecular screening assay using $(t t r$ sequence). The obtained results revealed that $21 \%$ of milk and dairy products (42/200) were positive for Salmonella species using enrichment culture-based PCR method, while $12 \%$ of different dairy samples (24/200) were found to be positive for Salmonella species by using the conventional culture methods. Two stool specimens out of 40 apparently healthy dairy handlers were positive by the PCR method. Serotyping of Salmonella isolates revealed that 58.3\% (14/24) from different dairy products were contaminated with Salmonella Typhimurium. We conclude that the enrichment culture-based PCR assay has high sensitivity and specificity for detection of Salmonella species in dairy products and handlers. High incidence of Salmonella Typhimurium in the examined dairy samples highlights the important role played by milk and dairy products as a vehicle in disease prevalence. Great effort should be applied for reducing foodborne risk for consumers.
\end{abstract}

\section{Introduction}

Foodborne diseases remain a major global public health concern. It does not only affect people's health and well-being, but it also has many economical drawbacks. In 2005, nearly $20 \%$ of acute diarrhea observed worldwide was attributed to bacterial enteropathogens. 1.8 million people die every year from diarrheal diseases mostly in developing countries. A great proportion of these cases can be due to contamination of food and drinking water [1]. Salmonella, Shigella, and Campylobacter are the principle pathogens responsible for $89 \%$ of bacterial gastroenteritis infections [2]. Salmonellosis is caused by the bacterium Salmonella enterica. Currently, there are more than 2500 Salmonella serotypes [3]. The most common infectious Salmonella species are Salmonella Enteritidis and Salmonella Typhimurium which together account for three-quarters of all salmonellosis cases each year. The majorities of human salmonellosis cases have been associated with the consumption of raw or inadequately heattreated dairy products [4]. The presence of Salmonella species in raw milk generally comes from feces of infected animals. Dairy cattle are the natural reservoirs of Salmonella species. Diagnosis of infected animals is difficult due to asymptomatic or subclinical infection and the fact that affected cows can shed as many organisms in their manure, providing an easy route of contamination during milking and milk processing [5]. Salmonella presence in milk and some dairy products emerged as major public health concern to human consumers, causing great public health problem, as salmonellosis is an important zoonotic disease and being one of the most commonly reported causes of foodborne disease over the past century [6]. The most commonly used technique for Salmonella detection is the traditional microbiological technique. In spite of being the gold standard, these methods are 
generally labor- and time-consuming, requiring a minimum of 4-6 days, therefore, increasing the risk of uptake or transmitting pathogens [7]. Culture methods have also been reported to show poor sensitivity for low-level contamination with a high background of indigenous microflora in the samples, rendering the recovery of target organism difficult [8]. Polymerase chain reaction (PCR) and more recently realtime PCR assays have been developed for the detection of Salmonellae or specific serotypes in a variety of foods [911]. Several PCR assays have been developed by targeting various Salmonella genes, such as 16S rRNA [12], agfA [13], $v i a B[14]$, and virulence-associated plasmids [15]. In addition, $\operatorname{tr} B C A$ sequences were specific for all Salmonella serovars [16]. In Egypt, salmonellosis remains a neglected zoonotic disease. In addition, there is lack of information available on the presence of Salmonella species in raw milk and some dairy products sold in Mansoura city at Dakahlia Governorate, Egypt. Therefore, the main objective of the present study was to screen the presence of Salmonella species in milk and some dairy products as well as some human samples to evaluate the role of milk and dairy products in transmitting such pathogenic bacteria to human beings and to assess the personal hygiene of dairy handlers as well as the potential hazards to consumers.

\section{Methods}

2.1. Sample Collection. A total of 200 samples of milk and dairy products (bulk farm milk, market raw milk, Damietta cheese, and kareish cheese, 50 each) were randomly purchased in their retail packs from different dairy farms and groceries located at Dakahlia Governorate, Egypt, in addition to 120 human samples consisting of hand swabs and stool specimens from dairy handlers as well as stool specimens from diarrheic patients; 40 each. The diarrheic patients attend the outpatient clinic of Gastrointestinal Tract Hospitals, Mansoura University, Dakahlia Governorate. The study was conducted in the period between December 2012 and May 2013. Swabs from human sources were transferred into sterile buffered peptone water (BPW). All samples were transported in a refrigerated box $\left(4-8^{\circ} \mathrm{C}\right)$ to the laboratory where the bacteriological analyses were done immediately.

2.2. Sample Preparation. Twenty-five grams of collected cheese samples were weighed in a blender bag and homogenized with $225 \mathrm{~mL}$ of $0.1 \%$ BPW using a blender [17]. Additionally, the collected hand and stool swabs in BPW were subjected to the same laboratory diagnostic techniques in the same manner as done for dairy products $[18,19]$.

2.3. Microbiological Methods. Isolation and identification of Salmonella were performed using techniques recommended by US Food and Drug Administration [20]. Briefly, $25 \mathrm{gm}$ or $\mathrm{mL}$ from the collected samples was preenriched with $225 \mathrm{~mL}$ of BPW and incubated for $24 \mathrm{hrs}$ at $37^{\circ} \mathrm{C} .0 .1 \mathrm{~mL}$ of preenriched culture was transferred to $10 \mathrm{~mL}$ rappaport vassiliadis (RV) Broth (Oxoid) and incubated at $41^{\circ} \mathrm{C}$ for 18 to 24 hrs. Finally, loopful from the selective enrichment broth was inoculated onto xylose lysine deoxycholate (XLD)
(Oxoid) agar and incubated at $37^{\circ} \mathrm{C}$ for (18 to 24$)$ hrs. The incubation period could be prolonged up to $48 \mathrm{hrs}$ for those not showing any growth during the $24 \mathrm{hrs}$ of incubation. Characteristic Salmonella colonies from examined samples, having a slightly transparent zone of reddish colour and a black centre, were subcultured on nutrient agar slants, then incubated at $37^{\circ} \mathrm{C}$ for 24 hours, and then stored at $4^{\circ} \mathrm{C}$ until identification analyses were performed.

\subsection{Identification and Characterization of Isolated Salmonella} Strains. Each stored isolate was streaked onto XLD agar plate and incubated at $37^{\circ} \mathrm{C}$ for 24 hours. Suspected colonies were identified microscopically after Gram staining. Then, biochemical identification was performed using Kligler iron agar (KIA), Christensen's urea agar, Simmon citrate agar, lysine iron agar (LIA), Voges-Proskauer (VP), methyl red (MR), and indole tests [18]. Salmonella strains confirmed by biochemical tests were differentiated serologically into serovars at the Central Laboratories of Egyptian Ministry of Health as previously described [21].

\subsection{Molecular Assays}

2.5.1. Extraction of DNA by Thermal Cell Lysis of Suspended Bacteria from Enrichment Broth. DNA was extracted from the aliquot of enriched samples in BPW. A $15 \mathrm{~mL}$ of enrichment broth was transferred to centrifugal tube and was then centrifuged at $4000 \mathrm{rpm}$ for $10 \mathrm{~min}$ in order to suspend cell pellets as much as we can obtain. The supernatant was discarded and the harvested cell pellet was resuspended in $1 \mathrm{~mL}$ sterile distilled water and transferred into $1.5 \mathrm{~mL}$ centrifuge tube and centrifuged at $14000 \mathrm{~g}$ for $10 \mathrm{~min}$. The supernatant was discarded carefully. The pellet was resuspended in $100 \mu \mathrm{L}$ of sterile distilled water by vortexing. The tube was centrifuged again at $14000 \mathrm{~g}$ for $10 \mathrm{~min}$, and the supernatant was discarded carefully. The pellet was resuspended once again in $100 \mu \mathrm{L}$ of sterile distilled water by vortexing and put in heat block at $95^{\circ} \mathrm{C}$ for $15 \mathrm{~min}$. After heat treatment, the cell debris was pelleted by centrifugation at $14000 \mathrm{~g}$ for $10 \mathrm{~min}$. The volume of the DNA containing supernatant was estimated by pipetting to a new microcentrifuge tube and varied from 40 to $60 \mathrm{~mL}$, due to differences in removing the supernatant during the different washing steps of the DNA isolation method. The DNA was stored at $-20^{\circ} \mathrm{C}$ until PCR assay was performed. An aliquot of $2 \mu \mathrm{L}$ of the supernatant was used as the template DNA in the PCR [22].

\subsubsection{Molecular Detection of Salmonella Species Using PCR.} The DNA extracted from enrichment broth was screened by PCR using primers ttr6 and ttr 4 for the amplification of a highly conserved DNA region ( $t$ tr sequence) specific for all Salmonella serovars according to Malorny et al. [16]. This region was encoded for tetrathionate reductase structural proteins. The ability to respire tetrathionate is likely to be significant within the life cycle of Salmonella spp. [23]. The sequences of the oligonucleotide primer sets used were ( $5^{\prime}$ CTCACCAGGAGATTACAACATGG3') as forward primer and $\left(5^{\prime}\right.$ AGCTCAGACCAAAAGTGACCA$\left.\mathrm{TC}^{\prime}\right)$ as reverse primer and the expected size was $94 \mathrm{bp}$ 


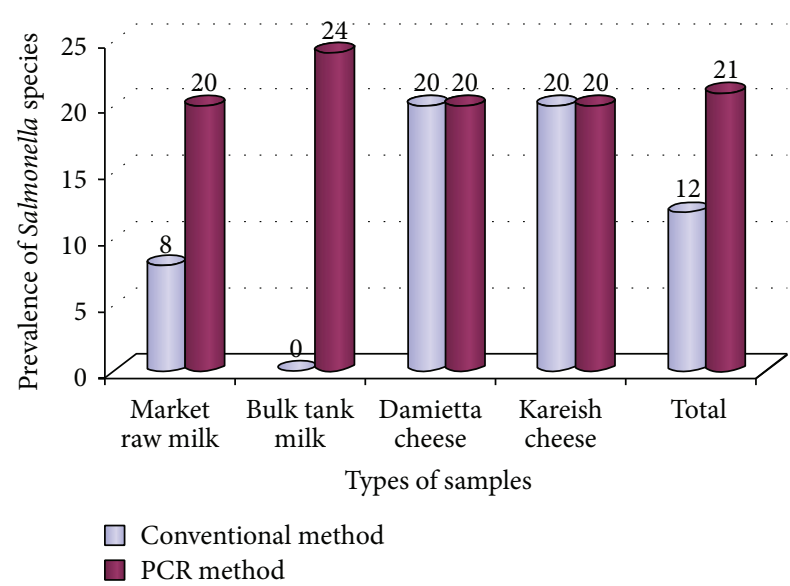

FIGURE 1: Prevalence of Salmonella species in the examined milk and dairy products samples.

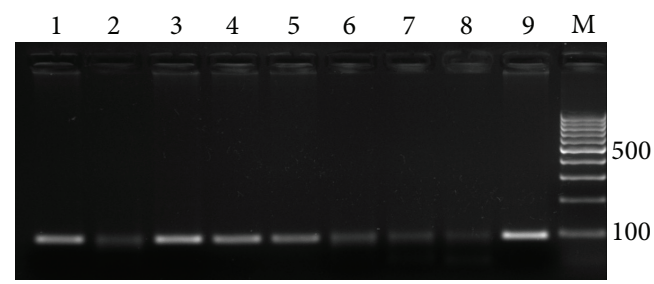

FIGURE 2: Agarose gel electrophoresis of ttr gene amplicon. lanes 1, 3,4 , and 5 are positive PCR product, lane 8 is negative control, lane 9 positive control, and lane 10 is DNA marker.

(Figure 2). PCR was performed with the Dream Taq Green PCR Master Mix (Fermentas). Cycling conditions were optimized at initial denaturation at $96^{\circ} \mathrm{C}$ for $1 \mathrm{~min}$, followed by 35 cycles of denaturation at $96^{\circ} \mathrm{C}$ for $15 \mathrm{sec}$, annealing at $60^{\circ} \mathrm{C}$ for $60 \mathrm{sec}$, and elongation at $72^{\circ} \mathrm{C}$ for $15 \mathrm{sec}$ with a final extension at $72^{\circ} \mathrm{C}$ for $1 \mathrm{~min}$. PCR products were visualized using ethidium bromide stained $2 \%$ agarose gel electrophoresis. The separated PCR products were then visualized under UV light and photographed.

\section{Results and Discussion}

The present study was conducted to shed light on Salmonella species isolated from milk and dairy products. Salmonella species, as a marker of food products safety, is widely distributed foodborne pathogen [24]. The presence and growth of Salmonella in milk and some dairy products have been investigated because of their health significance.

As shown in Figure 1, 21\% (42/200) of dairy products were positive for Salmonella species using enrichment culturebased PCR method, while 12\% (24/200) of different dairy samples were found to be positive for Salmonella species by using the conventional culture methods.

For market milk samples, 4 out of 50 with a percentage of $8 \%$ were positive for Salmonella species by conventional culture methods. Meanwhile, 10 out of 50 (20\%) were positive by PCR assay.
Regarding the bulk tank milk, it was found that 12 samples (24\%) were positive by PCR were culture negative. Salmonella species were not detected in any of the examined bulk tank milk samples by conventional culture methods. This result is in agreement with some researchers $[25,26]$ who failed to isolate Salmonella from their examined milk samples. On the contrary, high isolation rate $(2.7 \%)$ was previously obtained by other researchers [27]. It appears, from our results, that PCR assay is superior to the conventional culture methods for the detection of Salmonella species. While PCR offers rapid, sensitive, and specific detection of pathogens, its major disadvantage lies in its inability to evaluate viability due to the presence of DNA in dead cells, whereas cultural methods would only detect and enumerate viable cells [28]. Likewise, Salmonella species was not isolated from farm milk samples, but 12 samples were PCR positive. It seems likely that the bulk tank milk contains many other organisms that may interfere with the growth of Salmonella in the enrichment medium, keeping the total number of Salmonella lower than the detection limit on plates. Additionally, the presence of other organisms on XLD selective agar plates may interfere with the production of $\mathrm{H}_{2} \mathrm{~S}$ by Salmonella which is important for identification [29]. Fresh milk obtained from a healthy cow is virtually sterile, containing a low microbial load of less than $10^{3} \mathrm{CFU}$ per milliliter. Pathogenic bacteria can gain access to the milk through three main sources: within the udder, outside the udder, and from the surface of equipment used for milk handling and storage [30].

Cheese is a well-known milk product which has gained great popularity throughout the world for its health promotion; it is ready-to-eat (RTE) food product that does not undergo any further treatment to ensure their safety before consumption. Soft cheese is considered the most popular Egyptian dairy product. It is regularly consumed in the daily life of Egyptian people. Their manufacture and handling techniques are still primitive and unhygienic [31]; therefore, contamination of cheese with foodborne pathogens may occur at several stages. Our findings showed that Salmonella species were isolated from 10 out of 50 examined samples, with a percentage of $20 \%$ and all samples positive by conventional culture method were also positive by using PCR method. The main sources of pathogenic bacteria in cheese were contaminated raw milk, food handlers, dust, utensils, and insects [32]. Raw milk contaminated with Salmonella spp. and introduced into dairy processing plant constitutes a risk to human health. Our findings were higher than those obtained in a previous report that isolated Salmonella spp. from Kareish cheese with a percentage of 3.33\% [33]. However, several authors could not recover Salmonella species from Kareish cheese [34, 35]. Concerning the serotyping of 24 Salmonella positive strains yielded by conventional culture methods (Table 1), Salmonella enterica subsp. enterica serovar Typhimurium was considered the major cause of Salmonella infection among the examined raw market milk and Damietta and Kareish cheese. 58.3\% (14/24) of different dairy products were contaminated with Salmonella Typhimurium which poses great public health hazards. Consumption of contaminated milk and dairy products represents a common 
TABle 1: Prevalence of Salmonella serovars among milk and dairy products.

\begin{tabular}{lccc}
\hline Type of products & Salmonella species & Number & $\%$ \\
\hline Market milk $(n=50)$ & Salmonella Typhimurium & $\mathbf{4}$ & $\mathbf{1 6 . 7}$ \\
\hline Damietta cheese & Subsp. III Arizona serovar & $\mathbf{5}$ & $\mathbf{2 0 . 8}$ \\
$(n=50)$ & Salmonella Typhimurium & $\mathbf{5}$ & $\mathbf{2 0 . 8}$ \\
\hline \multirow{3}{*}{ Kareish cheese $(n=50)$} & Subsp. salamae serovar & $\mathbf{3}$ & $\mathbf{1 2 . 5}$ \\
& Subsp. III Arizona serovar & $\mathbf{2}$ & $\mathbf{8 . 3}$ \\
& serovar Typhimurium & $\mathbf{5}$ & $\mathbf{2 0 . 8}$ \\
\hline Total & & $\mathbf{2 4}$ & $\mathbf{1 0 0}$ \\
\hline
\end{tabular}

cause of human infection with salmonellosis. Salmonellae, particularly Salmonella Typhimurium and Salmonella Dublin, were commonly found in cattle and are excreted in the feces. That provides an easy route of contamination during milking and milk processing [36].

The results of market and bulk milk samples as well as both soft cheese samples did comply with neither Egyptian nor European standards, stating that milk and dairy products should be free from Salmonella [37-40]. National governments should provide more attention to ready-to-eat food as soft cheeses, from production time and throughout their expected shelf life. Many rapid, specific, and accurate protocols for detection should be provided and applied as well.

The overall percentage of Salmonella species in the total examined human samples was $1.7 \%$. Two stool specimens out of $40(5 \%)$ of the apparently healthy dairy handlers were positive by PCR assay. Asymptomatic infections with Salmonella species are thought to be common, although the proportion of patients who do not manifest disease is not known [41]. All collected hand swabs were found to be free from Salmonella. In contrast to our results, higher percentages of Salmonella among diarrheic people were previously reported by several authors [42-44] whose results were $13.6 \%$, $80.5 \%$, and $53.5 \%$, respectively. From the obtained data, we cannot ignore the role played by the apparently healthy carriers in dissemination of infection; hence, it was of utmost importance to examine stool samples of apparently healthy persons (nondiarrheic stool samples) to clarify their role in shedding of bacterial pathogens.

\section{Conclusion}

Rapid detection of pathogens in food is critical for the diagnosis of food poisoning and monitoring of food safety. Our findings represent the first report of using enrichment culture-based PCR method to detect Salmonella species in selected dairy products and handlers in Egypt and it can provide efficient and reliable results with high sensitivity and specificity. In our study, the dairy products sold in Dakahlia Governorate are contaminated with Salmonella species. These isolates constitute great public health hazards to consumers. National governments should apply periodical examination of dairy products to ensure consumers safety. Isolation of Salmonella species from apparently healthy dairy workers indicates bad hygienic standards and prerequisite regular worker inspection for surveillance of foodborne pathogens. Information on health hazards associated with contaminated dairy products should be provided to the public, so that consumption of untreated raw milk could be avoided.

\section{Ethical Approval}

A favorable ethical opinion was gained from the Ethical Committee of Mansoura University.

\section{Conflict of Interests}

None of the authors of this paper has a financial or personal relationship with other people or organizations that could inappropriately influence or bias the content of the paper.

\section{References}

[1] WHO, "Food safety \& food-borne illness," Fact Sheet 237, World Health Organization, Geneva, Switzerland, 2007.

[2] J. M. Streit, R. N. Jones, M. A. Toleman, L. S. Stratchounski, and T. R. Fritsche, "Prevalence and antimicrobial susceptibility patterns among gastroenteritis-causing pathogens recovered in Europe and Latin America and Salmonella isolates recovered from bloodstream infections in North America and Latin America: report from the SENTRY Antimicrobial Surveillance Program (2003)," International Journal of Antimicrobial Agents, vol. 27, no. 5, pp. 378-386, 2006.

[3] M. Y. Popoff, J. Bockemühl, and L. L. Gheesling, "Supplement 2002 (no. 46) to the Kauffmann-White scheme," Research in Microbiology, vol. 155, no. 7, pp. 568-570, 2004.

[4] A. Ellis, M. Preston, A. Borczyk et al., "A community outbreak of Salmonella berta associated with a soft cheese product," Epidemiology and Infection, vol. 120, no. 1, pp. 29-35, 1998.

[5] T. R. Callaway, J. E. Keen, T. S. Edrington et al., "Fecal prevalence and diversity of Salmonella species in lactating dairy cattle in four states," Journal of Dairy Science, vol. 88, no. 10, pp. 36033608, 2005.

[6] E. T. Ryser, "Public health concerns," in Applied Dairy Microbiology, E. H. Marth and J. L. Steele, Eds., pp. 263-403, Marcel Dekker, New York, NY, USA, 1998.

[7] W. H. Andrews and T. S. Hammack, "Chapter 5: Salmonella", in (Food and Drug Administration) Bacteriological Analytical Manual Online, 2003, http://www.cfsan.fda.gov/ ebam/bam5.html.

[8] J.-Y. D’Aoust, A. M. Sewell, and D. W. Warburton, "A comparison of standard cultural methods for the detection of foodborne Salmonella," International Journal of Food Microbiology, vol. 16, no. 1, pp. 41-50, 1992.

[9] R. Ferretti, I. Mannazzu, L. Cocolin, G. Comi, and F. Clementi, "Twelve-hour PCR-based method for detection of Salmonella spp. in food," Applied and Environmental Microbiology, vol. 67, no. 2, pp. 977-978, 2001.

[10] A. A. Bhagwat, "Rapid detection of Salmonella from vegetable rinse-water using real-time PCR," Food Microbiology, vol. 21, no. 1, pp. 73-78, 2004.

[11] S. H. Liming and A. A. Bhagwat, "Application of a molecular beacon-real-time PCR technology to detect Salmonella species contaminating fruits and vegetables," International Journal of Food Microbiology, vol. 95, no. 2, pp. 177-187, 2004. 
[12] K. Iida, A. Abe, H. Matsui, H. Danbara, S. Wakayama, and K. Kawahara, "Rapid and sensitive method for detection of Salmonella strains using a combination of polymerase chain reaction and reverse dot-blot hybridization," FEMS Microbiology Letters, vol. 114, no. 2, pp. 167-172, 1993.

[13] J. L. Doran, S. K. Collinson, J. Burian et al., "DNA-based diagnostic tests for Salmonella species targeting agfA, the structural gene for thin, aggregative fimbriae," Journal of Clinical Microbiology, vol. 31, no. 9, pp. 2263-2273, 1993.

[14] Y. Hashimoto, Y. Itho, Y. Fujinaga et al., "Development of nested PCR based on the via B sequence to detect Salmonella typhi," Journal of Clinical Microbiology, vol. 33, no. 3, pp. 775-777, 1995.

[15] J. Mahon and A. J. Lax, "A quantitative polymerase chain reaction method for the detection in avian faeces of Salmonellas carrying the spvR gene," Epidemiology and Infection, vol. 111, no. 3, pp. 455-464, 1993.

[16] B. Malorny, E. Paccassoni, P. Fach, C. Bunge, A. Martin, and R. Helmuth, "Diagnostic real-time PCR for detection of Salmonella in food," Applied and Environmental Microbiology, vol. 70, no. 12, pp. 7046-7052, 2004.

[17] APHA, Compendium of Methods for the Microbiological Examination of Foods, American Public Health Association, Washington, Wash, USA, 3rd edition, 1992.

[18] R. S. Hendriksen, A Global Salmonella Surveillance and Laboratory Support of the World Health Organization Laboratory Protocols (Identification of Salmonella), 2003.

[19] Health Protection Agency, "Detection of Salmonella species," National Standard Method. F13 3.1, 2008, http://www.hpastandardmethods.org.uk.

[20] U. S. Food and Drug Administration, FDA Bacteriological Analytical Manual, Washington, Wash, USA, 8th edition, 2001, http://www.vm.cfsan.fda.gov/_ebam/bam-5.html.

[21] M. Y. Popoff, Antigenic Formulas of the Salmonella Serovars, WHO Collaborating Centre for Reference and Research on Salmonella, Institut Pasteur, Paris, France, 8th edition, 2001.

[22] M. I. Queipo-Ortuño, J. De Dios Colmenero, M. Macias, M. J. Bravo, and P. Morata, "Preparation of bacterial DNA template by boiling and effect of immunoglobulin $g$ as an inhibitor in real-time PCR for serum samples from patients with brucellosis," Clinical and Vaccine Immunology, vol. 15, no. 2, pp. 293296, 2008.

[23] M. Hensel, A. P. Hinsley, T. Nikolaus, G. Sawers, and B. C. Berks, "The genetic basis of tetrathionate respiration in Salmonella typhimurium," Molecular Microbiology, vol. 32, no. 2, pp. 275287, 1999.

[24] A. Zadernowska and W. Chajęcka, "Chapter 18: detection of Salmonella spp. presence in food," in Salmonella-A Dangerous Foodborne Pathogen, B. S. M. Mahmoud, Ed., pp. 393-412, InTech, 2012.

[25] I. G. Abo-Elnaga, A. Hessain, and H. R. Sarhan, "Bacteria and food poisoning organisms in milk," Die Nahrung, vol. 29, no. 4, pp. 375-380, 1985.

[26] A. M. R. Gharieb, Studies on some zoonotic bacterial food borne infection, [M.V.Sc. thesis], Faculty of Veterinary Medicine, Zagazig University, Zagazig, Egypt, 2008.

[27] A. N. Hassanain, "Milk as a vehicle of multidrug resistant zoonotic bacteria to human," Veterinary Medical Journal Giza, vol. 54, no. 2, pp. 551-561, 2006.

[28] K. L. Josephson, C. P. Gerba, and I. L. Pepper, "Polymerase chain reaction detection of nonviable bacterial pathogens," Applied and Environmental Microbiology, vol. 59, no. 10, pp. 3513-3515, 1993.
[29] J. S. Van Kessel, J. S. Karns, L. Gorski, B. J. McCluskey, and M. L. Perdue, "Prevalence of Salmonellae, Listeria monocytogenes, and fecal coliforms in bulk tank milk on US dairies," Journal of Dairy Science, vol. 87, no. 9, pp. 2822-2830, 2004.

[30] R. L. Wallace, "Bacteria count in raw milk," in Dairy Cattle. Management, pp. 1-4, 2009, http://www.livestocktrail.illinois .edu/uploads/dairynet/papers.

[31] A. M. Al-Ashmawy, M. A. Mansour, I. H. Amer, and A. M. AbdEl-Haleem, "Studies on the microbiological quality of Egyptian Kareish and Mish cheese," Zagazig Veterinary Journal, vol. 22, 1994.

[32] R. K. Robinson, Dairy Microbiology, Chapman and Hall, London, UK, 2nd edition, 1990.

[33] O. H. R. El- Kosi, "Occurrence of some enteric pathogens and their indicators in some Egyptian raw milk products," Assiut Veterinary Medical Journal, vol. 45, no. 89, pp. 48-60, 2001.

[34] A. A. Bahout and A. H. Moustafa, "Occurrence of microorganisms in relation to public health in Kariesh cheese," Assiut Veterinary Medical Journal, vol. 52, no. 11, pp. 85-92, 2006.

[35] H. M. Fadel and J. Ismail, "Prevalence and significance of Staphylococcus aureus and enterobacteriaceae species in selected dairy products and handlers," International Journal of Dairy Science, vol. 4, no. 3, pp. 100-108, 2009.

[36] A. C. Baird-Parker, "Foodborne salmonellosis," The Lancet, vol. 336, no. 8725, pp. 1231-1235, 1990.

[37] Egyptian Standards"ES", "Soft cheese, part 2: cream cheeses, part 4: Kareish cheese," Egyptian Organization for Standardization and Quality Control 1008, Egyptian Standards“ES”, Arab Republic of Egypt, 2000.

[38] Egyptian Standards"ES", "Milk and Dairy products, part 1: raw milk," Egyptian Organization for Standardization and Quality Control 154-1, Egyptian Standards “ES”, Arab Republic of Egypt, 2005.

[39] British Standards Institution, Microbiological Examination of Dairy Purposes, London, UK, 1986.

[40] Council of the European Communities "EC", "Laying down the health rules for the production and placing on the market of raw milk, heat treated milk and milk based products," Official Journal of the European Communities, pp. 1-32, 1992.

[41] T. J. Humphrey, E. J. Threlfall, and J. G. Cruickshank, "Salmonellosis," in Zoonoses, Biology, Clinical Practice and Public Health Control, S. R. Palmer, L. Soulsby, and D. I. H. Simpson, Eds., pp. 191-205, Oxford University Press, New York, NY, USA, 1998.

[42] G. Samonis, S. Maraki, A. Christidou, A. Georgiladakis, and Y. Tselentis, "Bacterial pathogens associated with diarrhoea on the island of Crete," European Journal of Epidemiology, vol. 13, no. 7, pp. 831-836, 1997.

[43] J. T. M. Peresi, I. A. Z. C. Almeida, S. I. Lima et al., "Food borne disease outbreaks caused by Salmonella enteritidis," Revista de Saude Publica, vol. 32, no. 5, pp. 477-483, 1998.

[44] M. O. Wasfy, B. A. Oyofo, J. C. David et al., "Isolation and antibiotic susceptibility of Salmonella, Shigella, and Campylobacter from acute enteric infections in Egypt," Journal of Health Population and Nutrition, vol. 18, no. 1, pp. 33-38, 2000. 

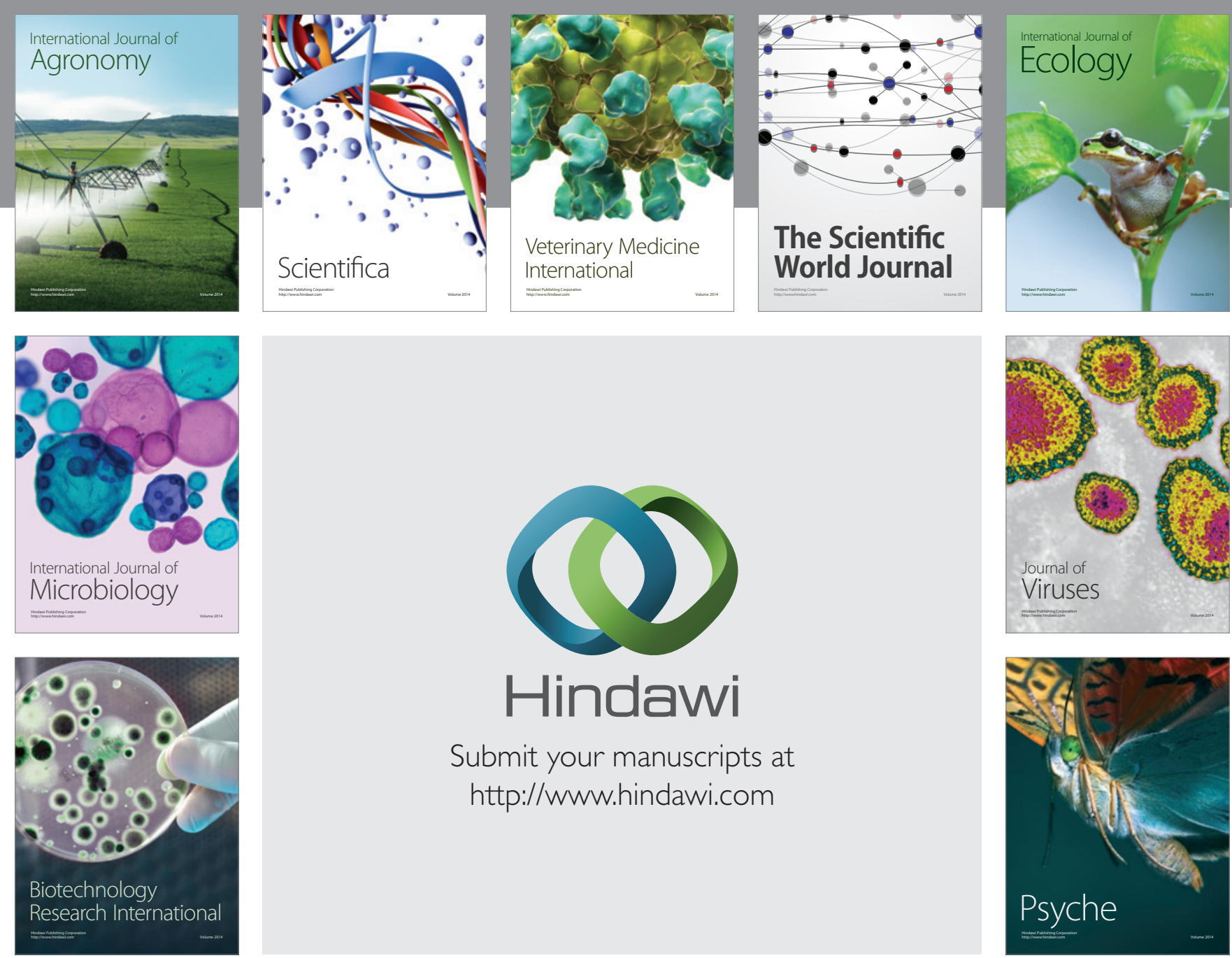

Submit your manuscripts at http://www.hindawi.com
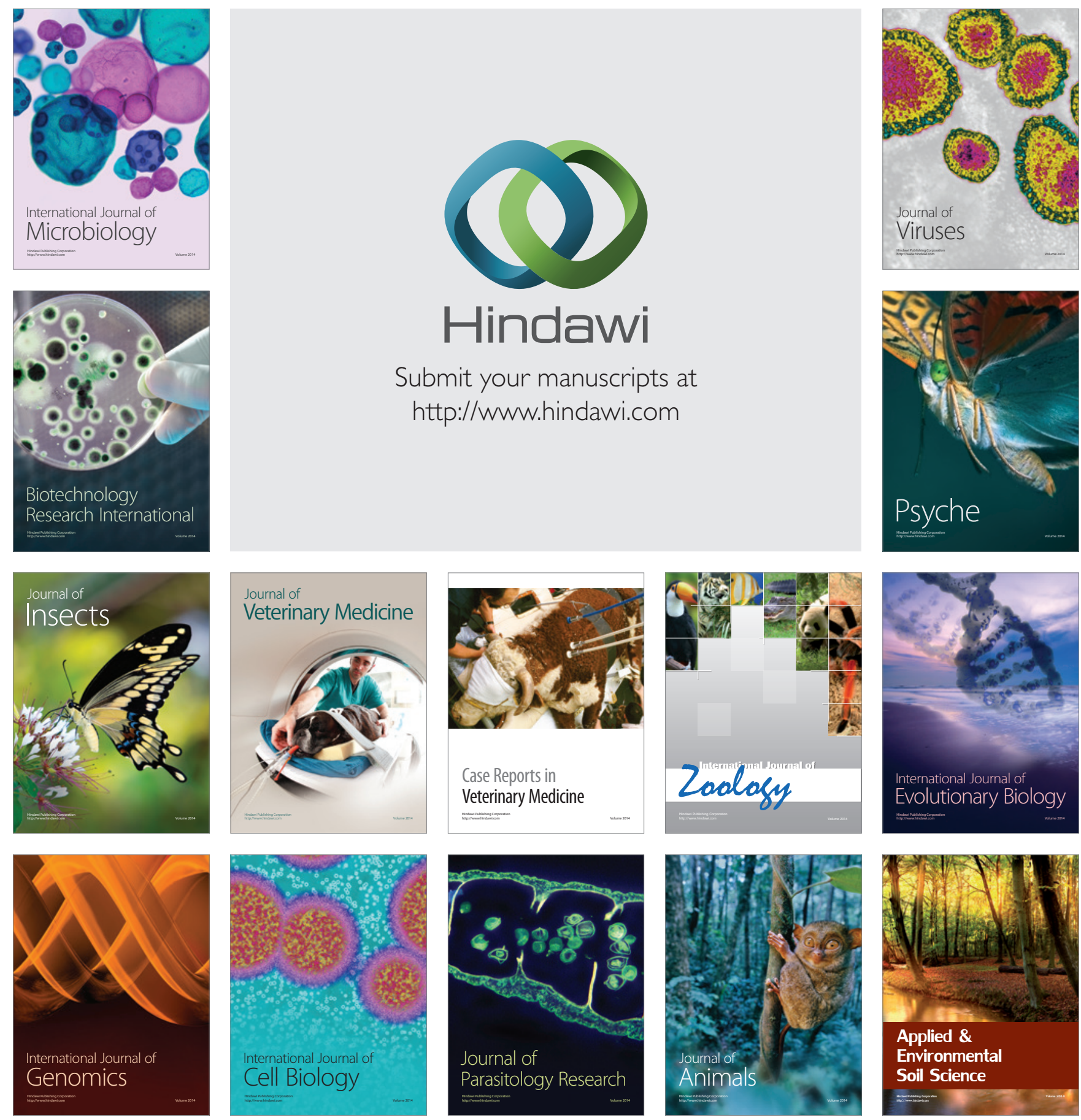